\title{
Neoliberal narratives of crisis: the feeble cries of a vanishing "class"
}

\author{
George Baca ${ }^{1}$
}

Published online: 14 November 2017

(C) Springer Science+Business Media B.V., part of Springer Nature 2017

In the most recent issue of Dialectical Anthropology, commemorating the 100th anniversary of the Russian Revolution, Lesley Gill raised critical historical questions about how the events of 1917 profoundly shaped the contemporary world. Gill's introduction dug underneath the current fascination with "neoliberalism" and underscored a decidedly darker side of the so-called Keynesian compromise. An imperial US State, in its Cold War hysteria, sought to stymy the reach of Bolshevism through what Gill describes as the "meddling and the threat of intervention" that made it "nearly impossible for left-leaning governments to succeed" (Gill 2017:202). Many of the essays, however, moved too quickly from the conceptual issue of revolution to an illdefined and emotionally saturated idea of neoliberal capitalism. In academic journals and leftleaning newspapers like The Guardian, neoliberalism represents a morality play: an evil form of capital committed to deregulation and privatization that has torn the be knighted Keynesian compromise between labor and capital asunder. In its place, a rather heartless form of capitalism rapaciously searches for easy profits at the expense of society.

Saygun Gökarısel's contribution follows this familiar pattern by depicting the way the dissolution of socialist Poland gave way to neoliberal capitalism. His essay "The ends of revolution: capitalist de-democratization and nationalist populism in the east of Europe," begins with a fascinating story about the ways class conflict raged in Communist Poland. The story centers on two disaffected Marxists - Jacek Kuron and Karol Modzelewski-who penned the legendary "Open Letter to the Polish United Workers' Party" in 1964. This radical critique of Eastern bloc communist states focused on the increasing class inequities and austerity. Indeed, Wladyslaw Gomulka's authoritarian regime reacted with hostility. As the government punished such activism, new political and economic fissures would continue to open up and dog the system for two more decades. This vivid picture of the complicated twists and turns of capital, struggles against the monopoly capitalism of Western Europe, and the rise of the Solidarity Movement leads predictably to a "crisis of liberal democracy" and the "dedemocratization" of neoliberalism.

George Baca

baca.george@gmail.com 
Gökarıksel's conceptual view seals off many questions by shoe-horning these contingent events into a predetermined age of neoliberalism. His use of the concept of neoliberalism undermines this critical moment by flattening history and sidetracking attention away from a wide variety of political actors, events, and struggles within Polish society. For example, he writes "with the so-called foreclosure of the symbolic and epistemic space of emancipation opened up by the French, Russian, and anti-colonial revolutions, we were supposed to step into the 'postrevolutionary' age of human rights, the rule of law, and neoliberal capitalism" (Gökarıksel 2017: 211). It is not clear whether he believes that the age of neoliberalism has "foreclosed" these emancipatory possibilities or if he is criticizing the free market ideologues who made these assertions. Either way, by conflating the Russian and French Revolutions, along with the messy processes of decolonization, he creates an ideal image of the past. In so doing, he describes the general logic of capital as if it were uniquely neoliberal-i.e., the relentless reducing of social life to a commodity form. Not to mention that the more significant legacy of the French Revolution was not liberation as much as the triumph of liberal capitalism. Against this naïve representation of a past full of democratic hope, he paints a horrific picture in "Poland and Eastern Europe, as in other parts of the world" where these possibilities have been shut down. In its steed, "a powerful rightwing populist formation has emerged to challenge the values and institutions of liberal democracy" and articulate "the problems of inequality and exclusion to their conservative nationalist language of sovereignty, security, and purity" (ibid: 209).

This well-worn storyline has been with us in the social sciences for several decades. It first emerged with the French Regulationists' formulation of "post-Fordism" in the 1970s (Aglietta 1976), then David Harvey popularized it in his book The Condition of Postmodernity (Harvey 1989). Now, it lives on in theories of neoliberalism (see Harvey 2007; Ong 2006; Duménil and Lévy 2004, 2011; Wacquant 2012). In this story, neoliberalism rises as a revolution against the fabled Keynesian compromise, takes away working class power, destroys the welfare state, and replaces democratic institutions with the logic of capital or governmentality. In such a narrative, neoliberalism comes to life in a threepronged attack of privatization, deregulation, and scaling back of social provision of the state. This storyline has been popular with US and Western European academics partly because it resonates with the living experience of people who formed part of the expanding middle class that was the centerpiece of the US's Cold War project. Perhaps concepts of neoliberalism and their narratives of crisis are better viewed as the feeble cry of a vanishing social group.

\section{Transporting western mythologies to the periphery}

The troubles with this concept, so deeply embedded in political mythology of western democracies, increase when foisted upon Eastern Europe and the global south. Many scholars from the USA have transported this narrative of decline to other parts of the world. The literature is rife with examinations of neoliberal capitalism in places that never experienced the postwar welfare state, relative affluence among the working class, and expansive consumerist lifestyles. The moral tale of decline creates a dissonance with people outside the west who primarily experienced western democracy, capitalism, and Keynesianism through the institutions of slavery, colonialism, and later, anti-communist aggression and development projects led by multinational corporations. 
In light of such contradictory relations between the rise of democracy and western capitalism's domination of the periphery, it is odd that Gökarıksel found Wendy Brown's account of "neoliberal de-democratization" relevant for analyzing post-Socialist Poland. In Undoing the Demos: Neoliberalism's Stealth Revolution, Brown simultaneously fashions an ideal image of American democratic past and its present crisis (Brown 2015). First, she clears the dirty side of postwar politics in the USA from our view. Anti-labor policies, the militarization of the industrial economy, and the state department's many imperial forays during the Cold War vanish from her recollection of Keynesianism. This allows her to focus the reader's attention on the ominous ways neoliberalism is tearing apart the West's vaunted tradition of democracy by battering down Keynesian safeguards. She warns us that neoliberalism has done more than "merely saturate the meaning or content of democracy with market values... [it] assaults the principles, practices, cultures, subjects, and institutions of democracy understood as rule by the people." She deepens the narrative by adding that "more than merely cutting away the flesh of liberal democracy," neoliberalism closes off future possibilities by "cauterizing" democracy's "more radical expressions, those erupting episodically across Euro-Atlantic modernity and contending for its future with more robust versions of freedom, equality, and popular rule than democracy's liberal iteration is capable of featuring" (2015:9).

Against such an ideal depiction of democracy in Cold War America, Brown provides a vivid example of how notions of crisis operate within neoliberal narratives. Rather than an analytic method for describing and analyzing political and economic changes since the 1970s, she fashions an image of crisis in an attempt to intensify the perceptions of change that have occurred (Baca 2010). Reinhart Koselleck points out that when "applied to history, "crisis," since 1780, has become an expression of a new sense of time which both indicated and intensified the end of an epoch. Perceptions of such epochal change can be measured by the increased use of crisis" (Koselleck 2006: 358). Indeed, the shrieks of crisis from such figures like George Monbiot, Gerard Duménil, Dominque Lévy, or Aihwa Ong mainly express this mood that an epochal change is afoot. Neoliberalism, accordingly, portends a dystopic future of markets and cutthroat capitalism cutting away the safety nets promised by democratic theories, a nationalist sense of belonging, and Keynesian structures. Never mind that for the majority of the world, this "epoch" shares many continuities with previous times.

It is hard to disagree with Brown about the devious ways that finance capital and multinational corporations operate in a profoundly anti-democratic manner. She is certainly right that "neoliberalism also cauterizes democracy's more radical expressions." But she misses an opportunity to make a deeper criticism of the way capitalism has disfigured what we take as democracy or democratic institutions. Ever since the invention of the democratic tradition in the West, and its political institutions and forms of power, capitalism has had powerful influence that has cauterized democracy's more radical expressions. The invention of democratic political ideals during the French Revolution was connected to capitalism and its modes of defying or superseding, the needs of "the people" (Sewell 2014).

Wendy Brown is not alone in venerating the past to denounce neoliberalism as a malevolent form of capitalism. In a recent book called The Neoliberal Pattern of Domination, economist José Manuel Sánchez Bermúdez offers another illustration of how a romanticized understanding of the past is mobilized to denigrate current modes of capital accumulation. Notwithstanding his more trenchant criticism of Keynesianism, he eventually succumbs to dramatic rhetoric by specifying neoliberalism as "financial capital's radical offensive" against "the working class of the whole world" that "constitutes an offensive against underdeveloped Capital" (Sánchez Bermúdez 2012: 157). Neoliberalism "frees the economy from the state" and "rolls 
back the conquests" of the French Revolution. Now neoliberalism is the evil contrast to the events that made "society master of its own house" through representative democracy, universal suffrage, and the social contract whereby "society could decide on the structure of its economy" (Sánchez Bermúdez 2012: 253). It may seem strange that a Marxist would take the political mythology of French Revolution at face value. But this is the sort of straightjacketing that the concept of neoliberalism achieves by seeking to stigmatize the present by mythologizing the past in ways that should embarrass.

Such romanticism stems from the way the French revolutionaries simultaneously bestowed bourgeois classes of Western European with a protean symbolism of democracy and popular sovereignty and a powerful central state. Revolutionary political language and mythology developed over the next two centuries in relation to the capitalist state in ways that confuse issues of democratic practice. Karl Marx famously described an essential legacy of these events when he wrote "the gigantic broom of the French Revolution" as having "swept away all these relics of bygone times, thus clearing simultaneously the social soil of its last hindrances to the superstructure of the modern state edifice" (Marx 1966: 64). The modern state would grow a symbiotic relation with industrial capital and the war industries. During the wars between 1792 and 1814, the state's powers would mature into a Leviathan that Thomas Hobbes could envy. So the relevance of the ideals of popular sovereignty and democracy arise in their crucial role for mobilizing its subjects, now renamed "citizens," to participate in wars, colonial projects, imperial invasions, not to mention the Keynesian compromise where labor in the west participated in an expanding and more rapacious imperialism (Neveling 2015).

By connecting the French Revolution with the repressive politics of capitalism does not mean that I believe that a "solid group of commercial and industrial interests" threw "off feudal shackles" and initiated a period of industrial expansion (Moore 1966: 105). As Moishe Postone points out, the more important criterion for the establishment of a capitalist order is not a bourgeois class. Alternatively, it is the generalizing power of the commodity form that gives rise "to a uniquely abstract form of social relations governed above all by a logic of exchange of equivalents in markets" (Postone 1995; cited in Sewell 2014: 11). Building on Postone's insights, William Sewell argues that "the eighteenth-century French commercial capitalist development fostered a vigorous growth of abstract forms of social relations and that the growing experience of such abstraction in daily life helped make the notion of civic equality both conceivable and attractive by the 1780s" (Sewell 2014:11).

Wendy Brown, among others, constructs neoliberalism as a "crisis," by underplaying this part of the historical process that welded capitalism to democratic practices and institutions. In this way, she is free to present neoliberal reason as a particularly nasty form of capitalism that not only allows "markets and money" to degrade democracy but converts "the operation of democracy's constituent elements into economic ones" (Brown 2015: 17). This image of "neoliberalism" eating away at the democratic values of equality for the sake of economics misconstrues a deeper understanding of the modern functioning of "modern universality" and "equality" (Postone 1995: 162). The spread of capitalism stems from a process that abstracts from the concrete and reduces them to a common denominator, the money form. Marx, then, would see Brown's democracy, based on a universality as the socio-historical precondition for the emergence of a popular notion of human equality, which rises from the alienation inherent in the commodity form. Therefore, it is important that we do not see democratic forms, institutions, and behaviors, as pre-existing these economic relations. 


\section{Keynesian capitalism and the silencing of the October Revolution}

If the French Revolution was "the gigantic broom" that swept away the remnants of feudalism, then the Russian Revolution was the specter that haunted the capitalist world into the hysteria of the Red Scare and the Cold War. The Russian Revolution significantly influenced the character and structure of capitalism by rearranging the global field of political power. By replacing Eastern Europe's most reactionary regime with a radical state, the Soviet Union unleashed new political pressures upon Western Europe and Britain. Vladimir Lenin inspired trade unionists and socialists as communism in Western Europe grew at a time when the ruling classes were in shambles after the folly of World War I.

Political instability and economic feebleness in Europe provided for the nightmares that inspired John Maynard Keynes's breakthroughs in political economy. He dreaded that Marxism's celebration of the common man could infect the British working classes with religious fervor that would sweep away the rationalism of the bourgeois intelligentsia, with whom he identified. In his essay A Short View of Russia, Keynes dismissed Marxism for the way it transformed an "obsolete economic textbook" into a sacred religious text. Further, he dismissed Marx's Capital as "scientifically erroneous" and irrelevant for the practical needs of the "modern world." In contrast to the immature posture of Bolshevism, Keynes extolled the "decent" and "intelligent" ideals of Western Europe. He found it difficult to imagine how "an educated, decent, intelligent son of Western Europe to find his ideals here, unless he has first suffered some strange and horrid process of conversion which has changed all his values" (Keynes 1963: 300). Without a useful "economic technique" or any "scientific value" to be found in Marxist economics, he was confident in his "British bourgeois ideals." (Ibid: 306)

Despite what he viewed as the weakness of Marxist economic principles, Keynes was terrified by what he perceived as the "religious" aspect of Leninism. He warned fellow travelers about the power of Bolshevism in mobilizing the masses by combining religion with economics. Because it was a "religion," communist doctrine was shorn from the rationalism and logic that should drive economic theories. Therefore, in the realm of politics, communist regimes had an advantage over western capitalism. Marxist regimes could easily mobilize popular support through the "exaltation of the common man" and thereby create a spiritual bond between its various "co-religionists." Capitalism, being based on rationalism and logic, "is absolutely irreligious, without internal union, without much public spirit, often, though not always, a mere congeries of possessors and pursuers." With this challenge, western capitalism would have to be "immensely, not merely moderately, successful to survive" (Keynes 1963: 306-307).

Such a political challenge led Keynes to develop a thorough criticism of his other enemies: laissez-faire capitalism and classical economics. Following his resignation from the Treasury Department at the Treaty of Versailles, he wrote the scathing criticism Economic Consequences of the Peace (1919), which gave a clear view of his anxieties:

Very few of us realise with conviction the intensely unusual, unstable, complicated, unreliable, temporary nature of the economic organisation by which Western Europe has lived for the last half century. We assume some of the most peculiar and temporary of our late advantages as natural, permanent, and to be depended on, and we lay our plans accordingly (Keynes, 1963:3). 
As such, it would be reckless to restore the Old Regime based on saving and accumulation of wealth. With a new environment, where Britain had to coexist with other industrialized countries, an expanded power of the state was necessary to ensure economic growth in a stable fashion.

Keynes' work provides us a window into the mind of a capitalist who is absolutely terrified by the sorry state of European capitalism and its feeble economic institutions amid the chaos unleashed by the disastrous Treaty of Versailles and the comedy of errors that produced the Great Depression (See Keynes 1963, 1936). Economist Hugo Radice points out that he "grasped more fully than anyone else the full political implications of the failure of capitalism." Moreover, Keynes understood the urgency in restoring the functioning of capitalism (Radice 2015: 29). His General Theory brutally criticized classical political economy and laissez-faire economic policies. It concluded that the expansion of the functions of the state was "the only practicable means of avoiding the destruction of existing economic forms in their entirety and ... the condition of the successful functioning of individual initiative" (Keynes 1936: 380). Rather than a compromise with the working class, he focused on developing institutions and concepts that would rein in the destabilizing effects of speculative capital. Capital controls and the concept of "effective demand" would be the center pieces of his schema that would strengthen the position of long-term capital investments (i.e., productive capital).

From this brief description of Keynes' dual critique of both Marxism and nineteenthcentury capitalism, it becomes clear that he is not the champion of the working class nor was he interested in creating a welfare state. To be sure, he rejected the Labor Party of the 1920s because it was a "class party, and the class is not my class." Granted, from these policy proposals, there was the development of higher wage employment and the focus on national self-sufficiency. But he also provided the theoretical basis for the expansion of the multinational corporation, which has become the central villain in narratives of neoliberalism. Maybe, it is time to replace the ideal of a Keynesian compromise, with a more critical examination of how the structures of capital, with the aid of Keynesianism compromised labor to capital's project of saving the capitalist system and its consolidation by the 1970s (Neveling 2017).

\section{The United States and Keynesian militarization}

Another critical problem contained in narratives of neoliberalism is the conflation of Keynes with the ways the US government employed specific Keynesian ideas to service its rapidly expanding military-industrial complex during the Cold War. Certainly, Keynesian economic principles were not a natural fit for the industrial elite of the USA during the 1930s. Initially, the business elite "vitriolically attacked" Keynesian reforms and refused to join. Notwithstanding such opposition, President Franklin Delano Roosevelt was desperate to find new economic ideas that could provide relief for the ravaged economy (Collins 1981). His administration expanded the powers of the state to readjust the banking industry, to develop industrial policy, and to expand the forces of production in agriculture.

With these successes, Roosevelt's administration discovered ways to calibrate New Deal reforms in ways that made sure industrialists would benefit from the state-ordered expansion of war production. With the war, business leaders "flocked into government service" and began celebrating the Keynesian policies connected to war preparation for "its prodigious feats of production." Indeed, the war provided businesses with significant incentives to expand 
capitalization and "form new groups in the shadowy areas where the private and public spheres intersected" (Collins 1981:81). The war effort legitimated these Keynesian institutions and established a pattern of business-government cooperation that would have far-reaching consequences in the postwar period (Blyth 2002: 79).

After the War, the USA had become the largest creditor nation and had emerged with the world's most powerful economy and military, which were deeply connected. Nevertheless, the US State Department and American business interests regarded the world to be full of many threats and challenges to its global ambitions. More than half of Europe was under Soviet Control. In the other half, there were active leftist movements that questioned capitalism (Varoufakis 2011). This effort to contain the communist threat was led by the group of "New Dealers" who had come to control the economy and the state since 1932 and had brilliantly orchestrated the War effort not only to establish an economic recovery and but to expand American power. Now, the US State Department began reworking Keynesian principles to stabilize the global system in ways that met the particular needs of American businesses and especially military industrialists. As Yanis Varoufakis describes:

The United States ... had no interest in restraining its own capacity to run large, systematic trade surpluses with the rest of the world. The New Dealers, however respectful they might have been of John Maynard Keynes, had another plan: a Global Plan, according to which the dollar would effectively become the world currency and the United States would export goods and capital to Europe and Japan in return for direct investment and political patronage - a hegemony based on the direct financing of foreign capitalist centres in return for an American trade surplus with them (Varoufakis 2011: 66-67).

Cold War hostility framed the supervision of the ex-colonial world. Thus, the rebuilding of the capitalist centers of the world would require a new relationship with the colonial world. The US State Department embedded the "welfare state" within its military machinery that would demand that the ex-colonial nations would participate in the new carbon-based democracy (Mitchell 2011). Indeed, Keynesian principles of effective demand and full employment required the increased exploitation of oil resources in Latin America and the Middle East. The postwar multilateral system expanded exploitive relations through the post-colonial development of sovereign nations "within which anti-colonial movements could move on from political independence to programmes of state construction" (Radice 2015: 164). The US government used the multilateral system to guide extraction of raw materials and especially oil for rebuilding global capitalism. These material needs would motivate the reconstitution of the colonial world into the "Third World." Laborers in the West received higher wages and gained new privileges that interconnected their rising consumerism with the new forms of imperial domination that secured raw materials necessary for the growth of this new type of capitalism based on the continuous growth of effective demand. In this way, the working classes of the USA and Western Europe became increasingly compromised.

\section{Conclusion}

The concept of neoliberalism represents a narrative that seeks to present contemporary forms of capitalism as a crisis to democracy. This story of decline turns on the idea of a grand Keynesian compromise that brought workers and capital together. Since neoliberal policies 
attack labor, pull apart welfare institutions, and seek to take apart public institutions, neoliberal theorists assume that Keynesianism was friendly to organized labor, was focused on welfare institutions, and attempted to redistribute money from the wealthy to create public goods. Such an uncritical reading of Keynesianism has led to a view that replaces the conservatism of Keynes with the aura of socialist or a social democrat. As I have pointed out, Keynes sought to build a stable edifice to rebuild capitalism to meet the political challenges represented by the Soviet Union. As such, he was not interested in helping organized labor nor expanding the welfare state. Instead, he focused on capital controls that would regulate speculative capital in ways that established a more stable environment for long-term capital investment. His view of long-term capital accumulation turned on the concept of "effective demand" that saw full employment and the growth of consumerism central to the health of the economy.

The other problem in the neoliberal narratives stems from the way they conflate Keynes' political economy with the ways the US Treasury transformed his principles to fire the industrial engine of its Cold War military-industrial complex. A criticism of contemporary neoliberalism should be connected to this political and economic complex rather than viewed as a "rupture." Contemporary critics of neoliberalism create this sense of a break with previous social forms by focusing on the "compromise" and skip over the Cold War appropriation of Keynesianism to massively expand the US economy. A more profound and critical view of neoliberalism could place it back into the more extensive history of capitalism, whereby the description of changes and novelty do not ignore continuities.

Acknowledgements The author would like to thank Jason Antrosio, Robert Beachy, Kirk Dombrowski, Gavin Smith, and Olga Fedorenko for providing useful comments and criticisms.

Funding information This study was supported by research funds from Dong-A University.

\section{References}

Aglietta, Michel. 1976. Régulation et crises du capitalisme. Paris: Calmann-Lévy.

Baca, George. 2010. Conjuring crisis: Racism and civil rights in a southern military city. New Brunswick: Rutgers University Press.

Baca, George. 2004. Legends of Fordism: Between myth, history, and foregone conclusions. Social Analysis 48 (3): 169-178.

Blyth, Mark. 2002. Great transformations: Economic ideas and institutional change in the twentieth century. Cambridge: Cambridge University Press.

Brown, Wendy. 2015. Undoing the demos: Neoliberalism's stealth revolution. Brooklyn: Zone Books.

Collins, Robert. 1981. The business response to Keynes: 1929-1964. Columbia University Press.

Duménil, Gerard and Dominique Lévy. 2004. Capital resurgent: Roots of the neoliberal revolution. Harvard University Press.

Duménil, Gerard, \& Dominique Lévy. 2011. The crisis of neoliberalism. Harvard University Press.

Gill, Lesley. 2017. Introduction. Dialectical Anthropology 41 (3): 201-205.

Gökarıksel, Saygun. 2017. The ends of revolution: Capitalist de-democratization and nationalist populism in the east of Europe. Dialectical Anthropology 41 (3): 207-224.

Harvey, David. 1989. The condition of postmodernity: An enquiry into the origins of social change. London: Blackwell.

Harvey, D. 2007. A brief history of neoliberalism. USA: Oxford University Press.

Keynes, John M. 1936. The general theory of employment, interest and money. London: Macmillan.

Keynes, John Maynard. 1963. Essays in persuasion. New York: W.W. Norton.

Koselleck, Reinhart. 2006. Crisis. Journal of the History of Ideas 67 (2): 357-400.

Marx, Karl. 1966. The civil war in France: The Paris commune. Peking: Foreign Languages Press.

Moore, Barrington. 1966. Social origins of democracy and dictatorship. Boston: Beacon.

Mitchell, Timothy. 2011. Carbon democracy: Political power in the age of oil. London: Verso Books. 
Neveling, Patrick. 2015. Export processing zones and global class formation. In Anthropologies of class power, practice, and inequality, ed. James Carrier and Don Kalb, 164-182. Cambridge: Cambridge University Press.

Neveling, Patrick. 2017. The global spread of export processing and the 1970s as the decade of 'consolidation'. In Changes in social regulation: State, economy, and social protagonists, ed. Knud Andersen and Stefan Müller, 23-40. Oxford and New York: Berghahn Books.

Ong, Aihwa. 2006. Neoliberalism as exception: Mutations in citizenship and sovereignty. Duke University Press.

Polanyi, Karl. 1944. The great transformation: Economic and political origins of our time. New York: Rinehart.

Postone, Moishe. 1995. Time, labor, and social domination: A reinterpretation of Marx's critical theory. London and New York: Cambridge University Press.

Radice, Hugo. 2015. Global capitalism: Selected essays. London and New York: Routledge.

Sánchez Bermúdez, José Manuel. 2012. The neoliberal pattern of domination: Capital's reign in decline. Leiden: Brill.

Sewell, William. 2014. Connecting capitalism to the French Revolution: The Parisian promenade and the origins of civic equality in eighteenth-century France. Critical Historical Studies 1 (1): 5-46.

Varoufakis, Yanis. 2011. The global Minotaur: America, Europe and the future of the global economy. Zed Books Ltd.

Wacquant, Loïc. 2012. Three steps to a historical anthropology of actually existing neoliberalism. Social Anthropology 21 (1): 66-79.

Wrigley, C.J. 1990. Lloyd George and the challenge of labour: The post-war coalition 1918-1922. London: Harvester Wheatsheaf. 